\title{
The Effectiveness Of Video-Online Education On Cadres' Knowledge And Attitude About The Importance Of Human Immunodeficiency Virus (HIV) Testing In Public Health Center
}

\author{
Gita Sekar Prihanti ${ }^{*}$, Aulia Devina Rizkitananda ${ }^{2}$, Dewinda Nur Mayaningsari ${ }^{2}$, Isti Eka Karunia ${ }^{2}$, \\ Mutiara Sukma Sholihah ${ }^{2}$, Ratika Velanuari Rostagama², Umar Asadullah ${ }^{2}$ \\ 1,2 Faculty of Medicine University of Muhammadiyah Malang, \\ Bendungan Sutami Street No. 188, 65145, Malang, Indonesia \\ Email: sekar@umm.ac.id
}

Received: September 29, 2020. Revised: November 28, 2020. Accepted: December 2, 2020.

Published: December 3, 2020.

\begin{abstract}
HIV education and tests are the main entrance for prevention, care and treatment support. Video as an educational tool, convey clear, consistent, and unbiased information while easy to use, effective as face-to-face interactions, yet, online-video has never been used in previous studies regardless of its easy-dissemination. Therefore, health cadres hold important tasks in educating people about the importance of HIV. To determine onlinevideo effectiveness on knowledge increment and cadres' attitude toward HIV testing importance in Public Health Centers. This study used a cross-sectional method with one group pretest and posttest models. The research sample was 50 HIV cadres using a total sampling technique. Data were analyzed using McNemar test to determine the comparison between pretest and posttest of knowledge and attitude variables. Research findings that before and after the intervention was carried out, there were differences in the results on the knowledge and attitude variables. Based on the McNemar test for the variables of knowledge and attitudes obtained significant results $(p=0.00)$. This research concludes that $o$ nline-video is effective in increasing knowledge and attitudes of HIV cadres toward the importance of HIV testing in Public Health Centers. In addition, it is necessary to have a combination of other interventions (FGD, flip sheets, counseling, leaflets) using a cohort or RCT method with a larger sample
\end{abstract}

Keywords-Chinese cabbage, growth-promoting bacteria, quality and treatment.

\section{INTRODUCTION}

Human Immunodeficiency Virus (HIV) is a virus attacks the human body and makes our immune system weak by destroying blood cells type needed for a normal immune System [1]. HIV has become a global emergency problem [2]. According to the UNAIDS HIV/AIDS epidemic report in 2018 reach 37.9 million, in the Asia Pacific region occupies 4th position after South Africa, Central Africa, and North Africa, which reach to 5.9 million. Indonesia occupies the fifth position most at risk of HIV/AIDS in Asia [3]. The prevalence of HIV/AIDS from 2015 to 2016 has increased from 30,935 to 41,250

East Java in 2017 occupies the first position in Indonesia with the highest increase in cases of 8,204 cases and the number of HIV cases in the Kediri city in 2018 was recorded 180 cases. From the obtained data, the coverage of people who are at risk of HIV infection who get an HIV check at the Sukorame Health Center is only $64.90 \%$ with a gap of $35.10 \%$ from the examination target [4].

There are several reasons for not achieving these targets, the existence of negative community and stigma about HIV, the lack of active role of community leaders in supporting HIV inspection program and referral system of cadres that are not yet running [5].

Health cadre is voluntary workers chosen by the community and as a duty to developing the community. In this case, the cadre is also referred to health promoter or promoter [6].Health cadre are important role in increasing knowledge and attitudes towards the importance of HIV examination. However, one obstacle in conducting HIV tests in the community is the lack of knowledge or training of HIV cadre [7]

From the results of research, [8] stated that one of the factors that can increase knowledge and attitudes in the community in preventing HIV is the existence of health education or education about HIV. Education about HIV can be provided by utilizing available multimedia technologies such as graphics and videos [9]. Whereas the results of research conducted by Siregar et al in 2019 stated that the health promotion method by means of evaluation in the form of filling out questionnaires before and after the intervention can increase knowledge and attitudes towards the dangers of HIV / AIDS. 
[10] explains that school students receive the most knowledge about HIV/AIDS from Television. [11] conducted on company workers and HIV experts also used media contains video of 16 minutes duration which were broadcasting in focus group discussions (FGDs). [12] that was conducted to patients resulting in an increase in knowledge about HIV, and this increase is persistent for 3 months. Knowledge or education about HIV plays an important role in raising public awareness about HIV testing or screening services and can improve health behavior in the community [6], [8], [13], [14] using participative video as an educational method was carried out for deep learning the teachers understanding of HIV and AIDS education as prevention which in the future would be taught to students in schools. So that important to increase knowledge and understanding of the importance of health promotion and HIV prevention which is carried out through an intervention by utilizing multimedia technology in the form of video to cadre [9], [15].

According to [4] can be said as an acceptable educational tool to get information clearly, consistently, impartiality, easily used, and can be as effective as face-to-face interaction. But in the two studies no one used online video as an alternative to providing education and making dissemination could wider.

By increasing the knowledge and attitudes of HIV cadres, and then evaluating them using a questionnaire before and after the intervention is also expected to increase public awareness to conduct HIV screening in health facilities. So that this study aims to determine the effectiveness of providing education through the online-video methods about the importance of examining the Human Immunodeficiency Virus (HIV) to increase the knowledge and attitudes of community cadres in the working area of the Sukorame Community Health Center.

\section{MATERIAL AND METHOD}

This research is an experimental study by providing intervention in a group of subjects. This research is using crosssectional one group pre-test and post-test design. In this study, the subject of previous research was carried out a pretest to find out the extent of respondents' knowledge and attitudes. After being given a pretest the respondent will be given intervention in the form of an HIV online video that contains information about the general picture of HIV, risk factors, how HIV is transmitted, HIV testing, and then a posttest is conducted

This research was conducted in the working area of Sukorame Kediri Public Health Center, namely the villages of Bandar Lor, Sukorame, Mojoroto, Pojok, and Bujel and the populations in this study were all cadres from each of these villages. Sampling using a total sampling technique that is as many as 50 people.

The instrument in this study used E-Questionnaire via Google form and containing 3 items. The first questionnaire was in the form of demographic data containing names, ages, sex, education, occupation, length of time as cadres, and never or never watched a video about HIV. The second questionnaire contained 28 questions for knowledge about HIV and 15 questions for attitude. E-questionaire Link from this research https://docs.google.com/forms/d/e/1FAIpQLSedxW5vOfSuB 7c3AGoJGEZLWlmlR_0TsGBbD8MfeLm2rhwaA/viewform.
The research variables consisted of videos, increasing cadre knowledge and cadre attitudes. The measuring instrument for variables is the knowledge and attitude questionnaire. The measurement results (indicators) variable, namely before and after the video show is playing. The variable measuring scale used is nominal.

Increased knowledge of the cadres referred to in this study is the understanding of cadres about the definition/symptoms, ways of transmission, clinical outcomes and HIV / AIDS therapy/prevention using 31 questionnaires [7]. The variable measurement tool is the knowledge questionnaire, the method of which is the pretest and posttest questionnaire by clicking on the statement column in the form of "yes" or "no". The measurement results (indicators) variables are 0-15: less while 16-31: good. And nominal variable measuring scale.

Increased cadre attitudes referred to in this study were cadre attitudes about HIV / AIDS using a questionnaire totaling 15 statements. The variable measurement tool is the knowledge questionnaire, the method is the Pretest and Posttest questionnaire by clicking on the statement column in the form of "agree," "disagree," and "not sure" where the answer "agree" is given a value, whereas "disagree" and " not sure "was given a zero value. The measurement result (indicator) variable was $<8.5$ negative while $\geq 8.5$ positive. And the scale of the nominal variable was measured.

The data collection technique was done by collecting data collected directly from respondents through the distribution of Google Form e-questionnaires and respondents filled out equestionnaires, watching HIV online videos, and then respondents were taken back data after finished watching HIV online videos. Then the primary data will be edited using Ms. excel, coding, presentation of results in tabular form, and McNemar data analysis.

Experimental design: The experimental design uses factorial randomized block design with 2 factors. The first factor is the soaking duration the seeds with PGPR solution namely $0,10,20$, and 30 minutes, while the second factor is the use of PGPR concentrations when watering the plants in the beds/bedengan (plant age 2 weeks), namely: $0 ; 1.25 ; 2.5$ and $3.75 \mathrm{~cm} 3 / \mathrm{L}$. The treatments were grouped into 3 groups so that 48 experimental units were obtained.

Data Analysis: The data that has been obtained will be analyzed using the SPSS for Windows 24 program. The analysis used in this study is univariate and multivariate analysis. Univariate analysis to determine the frequency distribution social demografi, education level, and long time to be a caders of respondents. Bivariate analysis to look for differences between independent variables with each dependent variable using the Mc Nemar test will find the comparison between the pretest and posttest of the knowledge and attitude variables.

\section{RESULTS AND DISCUSSION}

This research conduct on 41 HIV cadres in the working area of the Sukorame Health Center as shown in table 2. The pretest results of 5 respondent (12.2\%) had good knowledge and 36 respondent $(87.8 \%)$ had less knowledge about HIV, all 
of this is evident from the low level of education of the respondents with an average education level of senior high school. Whereas after respondents watched online videos about the importance of HIV testing and posttests, the results showed that the number of respondents with good knowledge increased to 40 respondents $(97.6 \%)$ which means as many as 35 respondents who initially had less knowledge increased to good knowledge, while the number of respondents who had less knowledge decreased to 1 respondent $(2,4 \%)$. Then the results of the pretest attitude were 8 respondents $(19.5 \%)$ who showed a positive attitude and 33 respondents $(80.5 \%)$ showed a negative attitude, This is all because on average new cadres work as cadres for a short time so that most of them have a negative attitude. After watching an online video about HIV testing and doing a post-test, the number of respondents who showed a positive attitude increased to 35 respondent (85.4\%) which means as many as 27 respondents who initially had a negative attitude increased to become positive attitude. while the number of respondents who still had bad attitudes was 6 respondents $(14,6 \%)$. This research shows that watching an online video about HIV testing can improve knowledge and attitudes of Sukorame Community Health Center cadres.

In Table 3, there are 5 knowledgeable respondents both before and after watching online videos. There were 35 respondents who initially had less knowledge turned into good knowledge after watching online videos about HIV and 1 respondent had less knowledge before and after watching online videos. While on the attitude test, there were 8 respondents who had positive attitudes before and after watching online videos, there were 27 respondents who initially had negative attitudes turned into positive attitudes after watching online videos about HIV and 6 respondents had negative attitudes before and after watching online videos.

Based on the McNemar test results as shown in table 3, a significant result was obtained ( $p<0.05$ ), that is $p=0.00$, so it can be interpreted that watching online videos about HIV there was an increase in the knowledge and attitudes of HIV cadres in the work place of the Sukorame City Health Center in Kediri between pre-test and posttests about HIV.

Discussion : Based on the results of statistical tests in this study, a significant value $(p<0.05)$ is obtained, $p=0.00$, so that it can be interpreted that there is a change in knowledge and attitudes towards respondents after watching online videos about HIV. This is shown in table 3.2, showing the result of the level of knowledge of respondents about HIV test, from 41 respondents it was 5 respondents had a good level of knowledge and 36 respondents had a level of lack of knowledge. Then respondents were given intervention in the form of online video playback. After being given an intervention, as many as 40 respondents showed good results while as many as 1 respondent showed less result. The results of the study are the same as the results of the study of [15] which conducted a study of a group of people aged 15-65 years by providing training to assess knowledge and attitudes about HIV and the importance of conducting HIV testing for 2 hours using audio-visual media. In this study knowledge and attitudes were assessed using a questionnaire given before and after the training and the results obtained in the form of an increase in knowledge and attitudes about the importance of health promotion and HIV prevention and increasing the number of visits to HIV testing.

Several advantages when using video media for intervention is cost-effective, and effective in increasing knowledge that can attract audience the attention of the images, sound, and movement. The Peyman and Jangi study, 2015 also explained that most people received knowledge about HIV / AIDS from videos on TV $(66.3 \%)$ then followed by newspapers/magazines (17.3\%), friends (10\%), and health workers $(8.7 \%)$ [16]. Providing education about HIV using visual narrative methods such as pictures and videos containing audio and text can have a positive impact on a community [17]. However, attention needs to be paid to the community's stigma about HIV, where interventions to reduce stigma are also important as additional tools for success in prevention [18]. In its research Flicker et al in 2019, 18 HIV activists made videos and then played in each community and conducted interviews afterward and gave positive results about participation in health campaigns especially about HIV.

It is also in accordance with [12] research that there is a difference in the intervention group with a p-value $\leq 0.01$, which means there is a significant difference in providing education with video media about HIV where there is an increase in knowledge about HIV, but the increase is only last for 3 months. It is also the same as [13] by using video as a promotional media, in this study they held a competition to make a video promoting HIV testing, after the intervention was then evaluated for 3 weeks, and from the study found that effective video media as a health promotion that contains messages about HIV testing. Furthermore, research conducted by [19] with the aim of determining whether the video increases knowledge about HIV / AIDS and HIV testing using a global sample of Internet users. Respondents filled out 25 questionnaire items to assess their knowledge of HIV / AIDS and their HIV tests before and after watching videos in English and Spanish. The average score on the questionnaire increased after watching the videos in both languages and there was no difference in the increase in scores between speakers of English and Spanish. So it can be concluded that video media is effective in increasing knowledge about HIV / AIDS. The results are the same as the research of [20], the study shows that interventions with Rational Emotive Digital Story are effective for increasing knowledge and perceptions of HIV / AIDS risk among school children in Nigeria. Even [21] research shows that online audio-visual education has a strong potential in increasing the prevalence of people for HIV screening and reducing sexual risk behavior. So it can be concluded that video media is effective in increasing knowledge about HIV / AIDS

The importance of increasing the number of visits for HIV screening as a preventive measure, WHO also recommends developed countries to maintain their efforts, while lagging countries must change their strategies to ensure the fulfillment of HIV screening services aimed at reducing the risk of HIV transmission [22]. According to [23] the existence of limited resources, operational barriers and limited outreach in educating the importance of HIV prevention, can be overcome by alternative methods of providing web-based education because it can enable widespread dissemination. But education directly gives better results when compared to providing education via web. Internet-based interventions can be 
educational and psychological. Education provides information about HIV / AIDS, while psychological which includes activities aimed at increasing social competence and resilience. It consists of three elements of emotional intelligence, effective social and communication skills, and resilience (identifying individual and family values and positive coping strategies) [24]. Social media interventions to increase public knowledge are also effective, according to [25], social media interventions are effective in promoting HIV testing in the community. Social media interventions to improve HIV services beyond HIV testing in low and middle-income countries need to be considered.

Good knowledge of HIV will increase public awareness of HIV testing at their own request, especially for high-risk communities, this is evidenced from participatory research that shows increased knowledge about HIV in the community and increasing community participation in HIV testing, HIV testing is mostly followed by sexually active young people. Good knowledge about HIV can also change HIV stigma and discrimination that have a significant impact on individual wellbeing and increase HIV prevention campaigns, programs and policies [7], [26].

Improving HIV training for public health staff, including addressing stigmatization, can help to increase the coverage of HIV testing in China [27]. Training can be an intervention choice to increase knowledge and with training it can increase the confidence of officers to provide advice to people at risk of HIV. Training programs for cadre need to be improved because it will have an impact on increasing cadre knowledge [28] According to [16] interventions especially interventions that help improve HIV / AIDS knowledge among students, positively changing students' attitudes towards HIV / AIDS.

However, the data from table 3.2 shows that 1 person has less knowledge after being given intervention, this is due to several factors that can influence people's knowledge, such as education level. Knowledge is very closely related to education where it is expected that someone with higher education, the person will be more knowledgeable [7]. In this study it is known that the respondent's last education was junior high school.

The effect of education with video media on the attitudes of respondents also showed significant analytic test results. Based on the distribution of data from respondents' attitudes about HIV testing it shows that of 41 respondents, 8 respondents had positive attitudes and 33 respondents had negative attitudes. Then after the same intervention, 35 respondents showed positive results while as many as 6 respondents showed negative results. That is because one of the factors that can increase health behavior in the community in preventing HIV is the existence of health education or education about HIV [8]. Education about HIV can be provided by multimedia technologies such as graphics and videos [9]. This is in accordance with the research of [29], based on the results of a study of attitudes in adolescents before and after being given interventions with leaflets and audiovisual media about the dangers of HIV / AIDS showing differences in attitudes before and after the intervention. In addition, according to [30] research regarding attitudes and stigma related to HIV / AIDS, this study shows that after instruction using visual media, there was a statistically significant increase in students' attitudes and stigma related to HIV.
In addition [31] shows that Maisha interventions can change people's stigma about people with HIV / AIDS. Maisha is a method of playing a video to a partner or woman who is doing antenatal care for the first time, where the video tells the story of a partner who is testing for HIV during antenatal care [30].

According to [32], knowledge and attitudes about HIV / AIDS are some of the important things in efforts to prevent HIV / AIDS. Knowledge, attitudes and practices are stages of behavior change or behavior formation. Therefore indicators for health attitudes are also in line with health knowledge

In the study of [8], there were significant differences between attitude scores before and after the intervention, the results showed a big change in the attitudes of health care workers. There can be seen an increase in attitude scores among health workers due to an increase in awareness of their health. However, research by [5] shows that positive attitudes and the desire to prevent HIV transmission are mostly only maintained for short periods after intervention.

But intervention using online video that requires respondents to have a smartphone and email address turned out to be one of the difficulties of this study. This is consistent with the study of [12] in South Africa that only $6 \%$ of participants in the survey preferred using social media to receive researchrelated information. This could be because cellular data in South Africa is still expensive and in some cases, internet technology may not always be accessible or can be used. In addition, some parents may not be comfortable with technology and therefore prefer to receive information in formats other than social media.

\section{CONCLUSION}

Online video is effective in increasing knowledge and attitudes of HIV cadres about the importance of HIV testing in the working area of the Sukorame City Health Center in Kediri because this research has found an increase in knowledge and attitudes towards HIV cadres in the work area of the Sukorame City Health Center in Kediri after watching online videos about HIV.

\section{RECOMMENDATIONS}

Suggestions for further research need to be done with a larger number of samples and follow-up for a longer period of time for 3 months to improve the results of knowledge and better attitudes. It is also necessary to carry out other different interventions such as Forum Group Discussion (FGD) or counseling with the addition of leaflets and leaflets on social media sites also need to be done to attract respondents.

Coordination of program managers for the prevention and control of diseases in each puskesmas with the local department to educate the public through online video innovations is important to increase knowledge and attitudes towards the importance of HIV testing.

\section{ACKNOWLEDGMENT}

This research was supported by all listed author/co-author for approval during the study, content from the video, data analysis and interpretation, and revision of the manuscript. This research did not get financial assistance from any party. 


\section{References}

[1] M. Abdu, A. Umar, B. H. I. Faisal, S. H. S. Tajuddin, B. I. Suria, and M. G. Yakasai, "Effectiveness of HIV/AIDS educational intervention in increasing knowledge, attitude and practices for primary school teachers in some part of Africa," HIV \& AIDS Review, vol. 15, no. 1, pp. 17-25, 2016.

[2] K. K. Case, L. F. Johnson, M. Mahy, K. Marsh, V. Supervie, and J. W. Eaton, "Summarizing the results and methods of the 2019 Joint United Nations Programme on HIV/AIDS HIV estimates," AIDS (London, England), vol. 33, no. Suppl 3, p. S197, 2019.

[3] C. K. Herbawani and D. Erwandi, "FAKTOR-FAKTOR YANG BERHUBUNGAN DENGAN PERILAKU PENCEGAHAN PENULARAN HUMAN IMMUNODEFICIENCY VIRUS (HIV) OLEH IBU RUMAH TANGGA DI NGANJUK, JAWA TIMUR," Jurnal Kesehatan Reproduksi, vol. 10, no. 2, pp. 89-99, 2019.

[4] O. Asan and E. Montague, "Using video-based observation research methods in primary care health encounters to evaluate complex interactions," Informatics in primary care, vol. 21, no. 4, p. 161, 2014.

[5] T. Khawcharoenporn, C. Srirach, and K. Chunloy, "Educational Interventions Improved Knowledge, Attitude, and Practice to Prevent HIV Infection among HIV-Negative Heterosexual Partners of HIV-Infected Persons," Journal of the International Association of Providers of AIDS Care (JIAPAC), vol. 19, p. $2325958219899532,2020$.

[6] F. W. Kalembo, G. E. Kendall, M. Ali, A. F. Chimwaza, and M. M. Tallon, "Primary caregivers, healthcare workers, teachers and community leaders' perceptions and experiences of their involvement, practice and challenges of disclosure of HIV status to children living with HIV in Malawi: a qualitative study," BMC public health, vol. 18, no. 1, p. 884, 2018.

[7] A. T.-W. Li, J. P.-H. Wong, R. Cain, and K. P.-L. Fung, "Engaging African-Caribbean, Asian, and Latino community leaders to address HIV stigma in Toronto," International Journal of Migration, Health and Social Care, 2016.

[8] H. A. Siuki, N. Peyman, M. Vahedian-Shahroodi, M. Gholian-Aval, and H. Tehrani, "Health education intervention on HIV/AIDS prevention behaviors among health volunteers in healthcare centers: An applying the theory of planned behavior," Journal of Social Service Research, vol. 45, no. 4, pp. 582-588, 2019.

[9] M. R. Khan et al., "The promise of multimedia technology for STI/HIV prevention: frameworks for understanding improved facilitator delivery and participant learning," AIDS and Behavior, vol. 16, no. 7, pp. 1949-1960, 2012.

[10] N. Peyman and M. Jangi, "The effect of educational intervention on knowledge, attitude and performance of high school girl students about AIDS," 2015.
[11] M. del C. Cabezas, M. Fornasini, D. Barmettler, D. Ortuño, T. Borja, and A. Albert, "Development of an educational video to improve HIV-related knowledge, attitudes and prevention among company workers in Ecuador," Health Education Journal, vol. 74, no. 1, pp. 120-127, 2015.

[12] M. Hendricks et al., "Impact of an educational video as a consent tool on knowledge about cure research among patients and caregivers at HIV clinics in South Africa," Journal of virus eradication, vol. 4, no. 2, p. 103, 2018.

[13] W. Tang et al., "Crowdsourcing HIV test promotion videos: a noninferiority randomized controlled trial in China," Clinical infectious diseases, vol. 62, no. 11, pp. 1436-1442, 2016.

[14] S. Mittal, "Application of the QUAIDS model to the food sector in India," Journal of Quantitative Economics, vol. 8, no. 1, pp. 42-54, 2010.

[15] J. Martínez Sanz et al., "Outcome of an HIV education program for primary care providers: Screening and late diagnosis rates," PloS one, vol. 14, no. 7, p. e0218380, 2019.

[16] H. Sarma, M. A. Islam, J. R. Khan, K. I. A. Chowdhury, and R. Gazi, "Impact of teachers training on HIV/AIDS education program among secondary school students in Bangladesh: A cross-sectional survey," PloS one, vol. 12, no. 7, p. e0181627, 2017.

[17] S. Flicker et al., "The impact of Indigenous youth sharing digital stories about HIV activism," Health promotion practice, vol. 21, no. 5, pp. 802-810, 2020.

[18] E. L. Bradley et al., "Developing FAITHH: Methods to develop a faith-based HIV stigma-reduction intervention in the rural south," Health promotion practice, vol. 19, no. 5, pp. 730-740, 2018.

[19] W. Shao et al., "Does a Video Improve Knowledge of HIV/AIDS and HIV Testing among a Global Internet Audience?," Journal of the International Association of Providers of AIDS Care (JIAPAC), vol. 15, no. 5, pp. 392-399, 2016.

[20] B. N. Ezegbe et al., "Rational emotive digital storytelling therapy for improving HIV/AIDS knowledge and risk perception among schoolchildren: A group randomized trial," Journal of Rational-Emotive \& CognitiveBehavior Therapy, vol. 37, no. 4, pp. 358-374, 2019.

[21] Z. Wang et al., "A randomized controlled trial evaluating efficacy of promoting a home-based HIV self-testing with online counseling on increasing HIV testing among men who have sex with men," AIDS and Behavior, vol. 22, no. 1, pp. 190-201, 2018.

[22] C. El Bcheraoui et al., "Health system strategies to increase HIV screening among pregnant women in Mesoamerica," Population health metrics, vol. 16, no. 1, p. 5, 2018.

[23] L. A. Marsch et al., "Comparative effectiveness of webbased vs. educator-delivered HIV prevention for adolescent substance users: a randomized, controlled trial," Journal of substance abuse treatment, vol. 59, pp. 30-37, 2015.

[24] L. del C. Castillo-Arcos, R. A. Benavides-Torres, F. López-Rosales, D. J. Onofre-Rodríguez, C. ValdezMontero, and L. Maas-Góngora, "The effect of an 
Internet-based intervention designed to reduce HIV/AIDS sexual risk among Mexican adolescents," AIDS care, vol. 28, no. 2, pp. 191-196, 2016.

[25] B. Cao et al., "Social media interventions to promote HIV testing, linkage, adherence, and retention: systematic review and meta-analysis," Journal of medical Internet research, vol. 19, no. 11, p. e394, 2017.

[26] S. Mathur, D. Romo, M. Rasmussen, N. Nakyanjo, F. Nalugoda, and J. S. Santelli, "Re-focusing HIV prevention messages: a qualitative study in rural Uganda," AIDS research and therapy, vol. 13, no. 1, pp. 1-9, 2016.

[27] J. J. Ong et al., "Opportunities and barriers for providing HIV testing through community health centers in mainland China: a nationwide cross-sectional survey," BMC infectious diseases, vol. 19, no. 1, p. 1054, 2019.

[28] A. Plowright, C. Taylor, D. Davies, J. Sartori, G. L. Hundt, and R. J. Lilford, "Formative evaluation of a training intervention for community health workers in South Africa: A before and after study," PloS one, vol. 13, no. 9, p. e0202817, 2018.

[29] K. Rochadi and N. Lubis, "The Effect Of Health Promotion Using Leaflets And Audio-Visual On Improving Knowledge And Attitude Toward The Danger Of Hiv/Aids Among Adolescents," International Journal of Nursing and Health Services (IJNHS), vol. 2, no. 3, pp. 172-179, 2019.

[30] A. A. M. M. Hussein ${ }^{1}$ and A. Amr, "The Effectof Instruction with Visual Materials on StigmaReduction Regarding Human Immunodeficiency Virus andAcquired Immune Deficiency Syndrome among University Students."

[31] M. H. Watt et al., "A counseling intervention to address HIV stigma at entry into antenatal care in Tanzania (Maisha): study protocol for a pilot randomized controlled trial," Trials, vol. 20, no. 1, p. 807, 2019.

[32] S. Notoatmodjo, "Metodologi Penelitian Kesehatan Jakarta: Rineka Cipta..(2007)," Promosi kesehatan teori dan ilmu perilaku. Jakarta: Rineka Cipta, 2002.
Creative Commons Attribution License 4.0 (Attribution 4.0 International, CM3 BY 4.0)

This article is published under the terms of the Creative Commons Attribution License 4.0

https://creativecommons.org/licenses/by/4.0/deed.en_US 
Table 1. Univariate Analysis

\begin{tabular}{|c|c|c|c|}
\hline Variable & Category & Quan-tity & Percentage (\%) \\
\hline \multirow[t]{2}{*}{ Age } & $21-30$ years old & 21 & 51 \\
\hline & $31-40$ years old & 20 & 49 \\
\hline \multirow[t]{2}{*}{ Gender } & Male & 26 & 63,4 \\
\hline & Female & 15 & 36,6 \\
\hline \multirow[t]{4}{*}{ Education } & Junior High School & 2 & 4,88 \\
\hline & Senior High School & 24 & 58,54 \\
\hline & Diploma & 6 & 14,63 \\
\hline & Bachelor & 9 & 21,95 \\
\hline \multirow[t]{5}{*}{ Occupation } & Housewife & 13 & 32 \\
\hline & Entrepreneur & 23 & 56 \\
\hline & Teacher & 3 & 7 \\
\hline & Civil servant & 1 & 2 \\
\hline & College student & 1 & 2 \\
\hline \multirow[t]{7}{*}{ Long been a cadre } & 5 months & 1 & 2 \\
\hline & 1 year & 8 & 20 \\
\hline & 2 years & 7 & 17 \\
\hline & 3 years & 8 & 20 \\
\hline & 4 years & 2 & 5 \\
\hline & 5 years & 10 & 24 \\
\hline & 8 years & 1 & 2 \\
\hline \multirow[t]{2}{*}{ Education about HIV } & Ever & 39 & 95 \\
\hline & Never & 2 & 5 \\
\hline
\end{tabular}

Source: data from laboratory analysis (2020)

Table 2. The results of pretest and posttest

\begin{tabular}{ccccc}
\hline & \multicolumn{2}{c}{ Posttest } \\
\hline Knowledge & $\mathrm{N}$ & $(\%)$ & $\mathrm{N}$ & $(\%)$ \\
Good & 5 & 12,2 & 40 & 97,6 \\
Less & 36 & 87,8 & 1 & 2,4 \\
Attitude & $\mathrm{N}$ & $(\%)$ & $\mathrm{N}$ & $(\%)$ \\
Positive & 8 & 19,5 & 35 & 85,4 \\
Negative & 33 & 80,5 & 6 & 14,6 \\
\hline
\end{tabular}

Table 3. Analysis of Bivariate Mc Nemar Test (Cross Tabulation)

\begin{tabular}{|c|c|c|c|c|c|}
\hline \multirow[t]{2}{*}{ Pretest } & \multicolumn{4}{|c|}{ Posttest } & \multirow{3}{*}{$\begin{array}{c}\mathrm{p} \\
\text { Value }\end{array}$} \\
\hline & \multicolumn{2}{|c|}{ Knowledge } & \multicolumn{2}{|c|}{ Attitude } & \\
\hline Knowledge & Good & Less & Positive & Negative & \\
\hline Good & 5 & 0 & - & - & 0,000 \\
\hline Less & 35 & 1 & - & - & \\
\hline Attitude & Good & Less & Positive & Negative & \\
\hline Positive & - & - & 8 & 0 & 0,000 \\
\hline Negative & - & - & 27 & 6 & \\
\hline
\end{tabular}

